\title{
Uusioersily
}

\section{Post-dispersal removal of seeds of pioneer species from five Panamanian forests}

Fornara, DA., \& Dalling, JW. (2005). Post-dispersal removal of seeds of pioneer species from five Panamanian forests. Journal of Tropical Ecology, 21(Part 1), 79-84. https://doi.org/10.1017/S026646740400197X

Link to publication record in Ulster University Research Portal

Published in:

Journal of Tropical Ecology

Publication Status:

Published (in print/issue): 01/01/2005

DOI:

10.1017/S026646740400197X

\section{Document Version}

Publisher's PDF, also known as Version of record

\section{General rights}

Copyright for the publications made accessible via Ulster University's Research Portal is retained by the author(s) and / or other copyright owners and it is a condition of accessing these publications that users recognise and abide by the legal requirements associated with these rights.

\section{Take down policy}

The Research Portal is Ulster University's institutional repository that provides access to Ulster's research outputs. Every effort has been made to ensure that content in the Research Portal does not infringe any person's rights, or applicable UK laws. If you discover content in the Research Portal that you believe breaches copyright or violates any law, please contact pure-support@ulster.ac.uk. 


\title{
Post-dispersal removal of seeds of pioneer species from five Panamanian forests
}

\author{
D. A. Fornara*1 and J. W. Dalling†
}

\author{
* Dipartimento di Biologia, Sezione Botanica Ambientale e Applicata, Università Statale di Milano, via Celoria 26, Milano, Italy \\ $\dagger$ Department of Plant Biology, University of Illinois, 265 Morrill Hall, 505 S Goodwin Avenue, Urbana IL 61801, USA \\ (Accepted 5 April 2004)
}

\begin{abstract}
Variation among forests in environmental and biotic conditions may strongly influence seed fate with important consequences for the abundance and distribution of plant species. Here we examine the post-dispersal seed removal rates of six pioneer species (Cecropia peltata, Miconia argentea, Luehea seemannii, Trema micrantha, Apeiba aspera and Jacaranda copaia) from the soil surface at five sites in Panama varying in elevation (0-1100 m) and seasonality (0-4 mo dry season). We compared removal rates of washed seeds placed in vertebrate exclosures, invertebrate exclosures, and unprotected controls in January and June. Overall, removal rates of unprotected seeds were similar among sites. Almost all seed removal could be attributed to litter ants in two subfamilies (Myrmicinae and Ponerinae). Little or no removal was recorded from invertebrate exclosures while vertebrate exclosures had no effect on removal either in lowland and montane forests. Seed removal rates were high for four animal-dispersed species (mean 45\% removed over $2 \mathrm{~d}$ ), whereas two wind-dispersed species were largely untouched (mean $2 \%$ removed). These results indicate that seed dispersal characteristics, rather than site characteristics, may be the strongest determinant of the post-dispersal seed fate of pioneers.
\end{abstract}

Key Words: environmental gradient, litter ants, seed dispersal, seed removal

\section{INTRODUCTION}

Recruitment of pioneer species during gap-phase regeneration is often dependent upon successful establishment from the soil seed bank (Cheke et al. 1979, Dalling \& Hubbell 2002, Guevara Sada \& Gómez-Pompa 1972, Lawton \& Putz 1988, Whitmore 1983). For establishment to take place, however, seeds must survive the activities of secondary dispersers and predators, avoid fungal infection, and remain sufficiently close to the soil surface for successful seedling emergence to occur. Seed burial experiments, radiocarbon dating, and comparisons between seed rain and soil seed densities indicate that species vary markedly in the capacity to survive these hazards, with seed persistence time for pioneers varying from a few weeks or less up to several decades (AlvarezBuylla \& Martínez-Ramos 1990, Dalling et al. 1997,

\footnotetext{
${ }^{1}$ Corresponding author, at Mammal Research Institute, Department of Zoology and Entomology, University of Pretoria, Pretoria 0002, South Africa.Email: dfornara@zoology.up.ac.za
}

Murray \& Garcia 2002, J. W. Dalling \& Brown, unpubl. data).

Seed fate may be primarily determined by seed size and morphology. Small-seeded species $(<1 \mathrm{mg}$ seed mass) are frequently removed by litter ants at the soil surface (Levey \& Byrne 1993), are susceptible to fungal pathogens (Dalling et al. 1998), and are only capable of successfully emerging from the surface few millimetres of soil (Pearson et al. 2002). Seed relocation by litter-dwelling ants in the forest understorey may increase chances of seedling recruitment for pioneer species (Levey \& Byrne 1993) since microsites suitable for germination and establishment are often patchy and scarce. However, most seed removal by ants probably results in seed predation (Levey \& Byrne 1993). In contrast, seeds $>10 \mathrm{mg}$ may exceed the maximum size that can be removed by litter ants (Kaspari 1996), or may have seed coats too thick for ants to penetrate (O'Dowd \& Hay 1980). However, largerseeded species may be more attractive to vertebrate seed predators.

Community-wide patterns of seed fate may also be influenced by site characteristics. The activity of seed 
Table 1. Location and characteristics of the five study sites.

\begin{tabular}{lcccc}
\hline Site & Location & Elevation $(\mathrm{m})$ & Rainfall $\left(\mathrm{mm} \mathrm{y}^{-1}\right)$ & Forest type \\
\hline Parque Metropolitano & $8^{\circ} 58^{\prime} \mathrm{N}, 79^{\circ} 34^{\prime} \mathrm{W}$ & 50 & 1740 & seasonal semi-deciduous \\
Barro Colorado Island & $9^{\circ} 10^{\prime} \mathrm{N}, 79^{\circ} 51^{\prime} \mathrm{W}$ & 70 & 2700 & seasonal semi-deciduous \\
Fort Sherman & $9^{\circ} 17^{\prime} \mathrm{N}, 79^{\circ} 58^{\prime} \mathrm{W}$ & 70 & 3500 & aseasonal wet forest \\
Cerro Campana & $8^{\circ} 40^{\prime} \mathrm{N}, 79^{\circ} 52^{\prime} \mathrm{W}$ & 800 & 2700 & pre-montane wet forest \\
Fortuna & $8^{\circ} 43^{\prime} \mathrm{N}, 82^{\circ} 14^{\prime} \mathrm{W}$ & 1100 & 3300 & montane wet forest \\
\hline
\end{tabular}

predators is likely to vary substantially along environmental gradients in tropical forests. Leaf litter ants rapidly remove small seeds and fruit from the soil surface at lowland sites, but their activity is positively correlated with soil moisture availability (Kaspari \& Weiser 2000, Levings \& Windsor 1984). Litter ants also decline in abundance at high elevation (McCoy 1990, Olson 1994, Samson et al. 1997), so that in contrast to lowland sites, they may be relatively unimportant as sources of seed loss in montane forest (Murray \& Garcia 2002). Rather less is known about the relative importance of vertebrates as predators of small seeds, although some evidence suggests that they may play a more important role in montane than in lowland forests (Murray \& Garcia 2002; K. G. Murray, personal communication).

In this study we examine removal rates of seeds of six pioneer species at five sites in Panama differing in rainfall, seasonality and elevation. We test whether species varying in seed mass and primary dispersal mode show differing removal patterns among sites, and use two exclosure treatments to evaluate whether removal is attributable to invertebrate or vertebrate predators and dispersers. We predict that invertebrate seed removal should increase with decreasing seasonality in the lowlands, and decrease with increasing elevation. We predict that vertebrate seed predation will only be important for the largest-seeded species (> $10 \mathrm{mg}$ dry mass).

\section{METHODS}

\section{Study sites and species}

The study was carried out from October 2000 to June 2001 at five sites varying in elevation, rainfall and seasonality, in the Republic of Panama (Table 1). Work was conducted within old-growth or old secondary forest (>80 y) at all these sites except Parque Metropolitano. Since accessible stands of old-growth lowland forest no longer occur along the Pacific coast of central Panama, work at Parque Metropolitano was conducted in secondary forest approximately $60 \mathrm{y}$ old, with a canopy dominated by long-lived pioneer and second-growth species (e.g. Luehea seemannii, Anacardium excelsum).

For seed removal experiments, we chose six pioneer species varying in seed size and dispersal characteristics common among the lowland sites (Table 2). All six species are common in the soil seed bank on Barro Colorado Nature Monument (BCNM). Four species are bird or mammal dispersed. Of these, Cecropia peltata (Cecropiaceae) and Miconia argentea (Melastomataceae) produce multi-seeded fleshy fruits and Trema micrantha (Celtidaceae) produces fleshy single-seeded fruits. Apeiba aspera (=A. membranacea, Tiliaceae, in Croat 1978) produces hard, spine-covered, multi-seed fruits that are either opened by monkeys in the canopy or by rodents on the ground. Individual Apeiba seeds are coated in an oily mesocarp that adheres strongly to the seeds. Our remaining two species are wind dispersed. Luehea seemannii (Tiliaceae) has a single elongated wing (samara) $1 \mathrm{~cm}$ long. Jacaranda copaia (Bignoniaceae) has a membranaceous circular wing surrounding the seed $2 \mathrm{~cm}$ in diameter. Detailed descriptions of these species (henceforth identified by genus name only) including their range distributions are found in Croat (1978).

\section{Seed removal experiments}

Seeds of all species were collected at BCNM. Seeds of Trema, Cecropia and Miconia were washed to remove all fruit pulp.

Table 2. Characteristics of species chosen for seed removal experiments. Sites: $\mathrm{M}=$ Parque Metropolitano, $\mathrm{B}=$ Barro Colorado Island, $\mathrm{S}=$ Fort Sherman, $\mathrm{C}=$ Cerro Campana, $\mathrm{F}=$ Fortuna.

\begin{tabular}{|c|c|c|c|c|}
\hline$\overline{\text { Species }}$ & Seed mass (mg) & Primary dispersal agent & Seed morphology ${ }^{1}$ & Sites present \\
\hline$\overline{\text { Miconia argentea (Sw.) DC. }}$ & 0.08 & monkey, bird & pyramidal & M, B, S, C \\
\hline Cecropia peltata $\mathrm{L}$. & 0.5 & monkey, bird, bat & obovoid & M, B, S, C \\
\hline Luehea seemannii Tr. \& Planch. & 1.0 & wind & samara & $\mathrm{M}, \mathrm{B}$ \\
\hline Jacaranda copaia (Aubl.) D. Don. & 4.7 & wind & winged disc & M, B, S \\
\hline Trema micrantha (L.) Blume* & 1.4 & bird & ovoid & $\mathrm{M}, \mathrm{B}, \mathrm{S}, \mathrm{C}, \mathrm{F}$ \\
\hline Apeiba aspera Spruce & 14.2 & monkey & irregular ovoid & $\mathrm{B}, \mathrm{S}$ \\
\hline
\end{tabular}

\footnotetext{
${ }^{1}$ Morphology of diaspore after primary dispersal.

*'small-seeded morphotype' sensu Silvera et al. (2002).
} 
Seeds of Apeiba were collected from fruits opened and discarded on the ground. Although Apeiba seeds were thoroughly washed small fragments of fruit pulp remained adhered to the seeds. Seeds of Luehea and Jacaranda were collected from unopened capsules. Seeds of all species were stored in an air-conditioned room before use. In OctoberNovember 2000 we set up 60 seed removal stations (10 stations for each of the six study species) at each of the five sites. Stations were randomly assigned to a seed species and were at least $5 \mathrm{~m}$ apart along a randomly located transect. Some stations were relocated to avoid treefall gaps. Each station consisted of a pair of 9-cm-diameter, upside-down Petri dishes, $10 \mathrm{~cm}$ apart, sheltered by a transparent $0.8-\mathrm{m}^{2}$ plastic tent to protect our seeds from being washed off by rain or contaminated by other falling seeds. One dish was assigned to an 'antfree' treatment made by smearing $1 \mathrm{~cm}$ around the edge of the dish with Tanglefoot ${ }^{\circledR}$ (Tanglefoot Co., Grand Rapids, Michigan, USA), a sticky paste that prevented crawling insects from moving onto the plate. The other dish remained untreated. Each dish received 10 seeds of one of the six species.

Observations of seed removal were conducted simultaneously on 30 of the 60 stations. At 10 h00 seeds were placed on alternate stations at least $10 \mathrm{~m}$ apart along the transect. Seed removal was recorded every hour until 16h00. Stations were re-censused the following morning starting at $10 \mathrm{~h} 00$ and hourly until $16 \mathrm{~h} 00$. A final census of the number of remaining seeds was made at $09 \mathrm{~h} 00$ on the third day. At $10 \mathrm{~h} 00$ on the third day fresh seeds were placed out on the remaining 30 stations and monitored as above. Specimens of ants carrying seeds were collected at the stations. Ants were removed from Petri dishes only when large numbers of ants had recruited to a station. Otherwise, ants were collected from around the Petri dish just after seed removal. Ant removal may therefore have reduced removal rates in a few instances (see also Kaspari 1993). Vouchers of ants collected during the experiments are deposited in a collection on BCI.

A second set of experiments was carried out at the same study sites with a subset of species in May-June 2001. At the same locations in each site as used in the first set of experiments we set up stations with different treatments. On this occasion, one of each pair of Petri dishes was enclosed within an 11-cm-diameter, 30-cm-high cylinder constructed from $0.6-\mathrm{mm}$ steel mesh designed to exclude vertebrate seed removal. Because of limited seed supply, stations were set up for three of the species: Apeiba, Luehea and Cecropia. In contrast to the first experiment, we used Luehea seeds from which the wing had been removed. Seeds were placed out in stations at $10 \mathrm{~h} 00$ and observations made at $11 \mathrm{~h} 00$ and every $2 \mathrm{~h}$ until $15 \mathrm{~h} 00$. We repeated the observations the following day starting at $10 \mathrm{~h} 00$ and hourly until $15 \mathrm{~h} 00$. A final census of the number of remaining seeds was made at $09 \mathrm{~h} 00$ on the third day. Ants were collected as above.

\section{Data analysis}

Differences in seed removal among species, treatments and sites were compared using analysis of deviance. Since the dependent variable, remaining seed number, is discrete, and the data are overdispersed (with the variance:mean ratio $>1$ ), we assumed a negative binomial error distribution. All models were fitted by maximum likelihood methods using Crawley's negative binomial errors macro implemented in the statistical program GLIM 3.7 (Crawley 1993).

\section{RESULTS}

\section{Effect of exclosure treatments on seed removal}

Most seed removal we observed could be attributed to small invertebrates. Over the total observation period, no seeds of Cecropia or Miconia were removed from the insect exclosure treatment. Likewise, minimal numbers of Trema (6/500), Luehea (3/500) and Jacaranda (1/500) seeds disappeared, the latter two species perhaps moved by the wind. Only the larger-seeded Apeiba had substantial numbers of seeds removed from the insect exclosure treatment, predominantly from the higher-elevation sites of Cerro Campana (20/100 seeds), and Fortuna (32/100 seeds). Only five Apeiba seeds were removed from the insect exclosure treatment at the remaining three sites. Given the low removal rate from the insect exclosure treatment, the mesh cage treatment designed to exclude vertebrates was not expected to influence removal rates except for Apeiba. In fact, we found no cage effect on removal for any of the three species tested (Cecropia, Luehea and Apeiba, $\mathrm{F}=0.7 ; \mathrm{df}=1,270 ; \mathrm{P}>0.05 ;$ Table 3). Finally, removal of the samara wing from Luehea seeds did not substantially increase rate of seed removal (Table 3).

Table 3. Mean per cent seed removal \pm SE from vertebrate caged and uncaged stations in May-June 2001. Wings were cut off seeds of Luehea.

\begin{tabular}{|c|c|c|c|c|c|c|c|c|c|c|c|c|}
\hline \multirow[b]{2}{*}{ Species } & \multicolumn{2}{|c|}{ Metropolitano } & \multicolumn{2}{|c|}{$\mathrm{BCI}$} & \multicolumn{2}{|c|}{ Sherman } & \multicolumn{2}{|c|}{ Campana } & \multicolumn{2}{|c|}{ Fortuna } & \multicolumn{2}{|c|}{ All sites } \\
\hline & Caged & Uncaged & Caged & Uncaged & Caged & Uncaged & Caged & Uncaged & Caged & Uncaged & Caged & Uncaged \\
\hline Apeiba & $29 \pm 4$ & $27 \pm 4$ & $36 \pm 4$ & $35 \pm 3$ & $60 \pm 12$ & $68 \pm 4$ & $98 \pm 6$ & $100 \pm 0$ & $80 \pm 3$ & $72 \pm 3$ & $61 \pm 4$ & $61 \pm 4$ \\
\hline Cecropia & $58 \pm 4$ & $74 \pm 4$ & $18 \pm 3$ & $17 \pm 3$ & $18 \pm 3$ & $29 \pm 3$ & $27 \pm 4$ & $34 \pm 5$ & $44 \pm 5$ & $49 \pm 4$ & $33 \pm 4$ & $41 \pm 4$ \\
\hline Luehea & $11 \pm 3$ & $17 \pm 2$ & $8 \pm 2$ & $5 \pm 8$ & $3 \pm 4$ & $8 \pm 0.8$ & $4 \pm 1$ & $25 \pm 3$ & $4 \pm 1$ & $3 \pm 0.7$ & $6 \pm 2$ & $12 \pm 2$ \\
\hline
\end{tabular}


Table 4. Number of seed stations from which at least one seed was removed ('stations visited', $\mathrm{n}=10$ ) and mean per cent number of seeds removed \pm SE at each study site for seeds exposed to insects in October-November 2000.

\begin{tabular}{|c|c|c|c|c|c|c|c|c|c|c|c|}
\hline & \multicolumn{2}{|c|}{ Metropolitano } & \multicolumn{2}{|c|}{$\mathrm{BCI}$} & \multicolumn{2}{|c|}{ Sherman } & \multicolumn{2}{|c|}{ Campana } & \multicolumn{2}{|c|}{ Fortuna } & \multirow{2}{*}{ 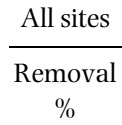 } \\
\hline & $\begin{array}{c}\text { Stations } \\
\text { visited }\end{array}$ & $\begin{array}{c}\text { Removal } \\
\%\end{array}$ & $\begin{array}{c}\text { Stations } \\
\text { visited }\end{array}$ & $\begin{array}{c}\text { Removal } \\
\%\end{array}$ & $\begin{array}{c}\text { Stations } \\
\text { visited }\end{array}$ & $\begin{array}{c}\text { Removal } \\
\%\end{array}$ & $\begin{array}{c}\text { Stations } \\
\text { visited }\end{array}$ & $\begin{array}{c}\text { Removal } \\
\%\end{array}$ & $\begin{array}{c}\text { Stations } \\
\text { visited }\end{array}$ & $\begin{array}{c}\text { Removal } \\
\%\end{array}$ & \\
\hline Miconia & 6 & $40 \pm 4$ & 7 & $43 \pm 4$ & 5 & $33 \pm 2$ & 5 & $28 \pm 1$ & 6 & $42 \pm 2$ & $37 \pm 3$ \\
\hline Cecropia & 8 & $70 \pm 15$ & 7 & $56 \pm 15$ & 7 & $29 \pm 12$ & 4 & $17 \pm 10$ & 7 & $33 \pm 1$ & $41 \pm 10$ \\
\hline Luehea & 1 & $10 \pm 10$ & 2 & $2 \pm 1$ & 1 & $2 \pm 2$ & 0 & 0 & 0 & 0 & $3 \pm 2$ \\
\hline Jacaranda & 0 & 0 & 2 & $3 \pm 2$ & 0 & 0 & 0 & 0 & 0 & 0 & $0.6 \pm 0.6$ \\
\hline Trema & 8 & $55 \pm 1$ & 10 & $80 \pm 10$ & 9 & $23 \pm 9$ & 7 & $49 \pm 15$ & 9 & $35 \pm 8$ & $49 \pm 10$ \\
\hline Apeiba & 8 & $29 \pm 1$ & 10 & $96 \pm 3$ & 8 & $64 \pm 13$ & 8 & $31 \pm 10$ & 9 & $54 \pm 10$ & $55 \pm 12$ \\
\hline All species* & 30 & $49 \pm 9$ & 34 & $69 \pm 11$ & 29 & $37 \pm 9$ & 24 & $31 \pm 7$ & 31 & $41 \pm 5$ & $45 \pm 6.6$ \\
\hline
\end{tabular}

*Excluding Luehea and Jacaranda.

\section{Variation in removal rates among sites and species}

Here we only consider the fate of seeds exposed to insects in October-November 2000 (Table 4). Removal rates were strikingly different for seeds with primary dispersal by wind versus animals. Samaras of the wind-dispersed Luehea were untouched at two of the sites, and only few seeds were removed from each of the remaining three sites. Similarly only three winged seeds of Jacaranda were removed from BCI and untouched elsewhere (Table 4). In contrast, a substantial fraction of the four animaldispersed seeds were removed over the same time period, ranging from $17 \%$ for Cecropia at Campana to $96 \%$ for Apeiba at BCI (Table 4).

For the four animal-dispersed species, we found a significant effect of site on seed removal $(\mathrm{F}=2.46 ; \mathrm{df}=4,180$; $\mathrm{P}<0.05)$, but no significant effect of species ( $\mathrm{F}=0.97$; $\mathrm{df}=3,180 ; \mathrm{P}>0.01)$ or site $\times$ species interaction $(\mathrm{F}=$ $0.89 ; \mathrm{df}=12,180 ; \mathrm{P}>0.01)$. Differences among sites in seed removal could be attributed to the higher removal at BCI (mean 69\%) than at the other sites (mean 39\%; Table 4). Explanations for this site effect are unclear, and suggest higher litter invertebrate densities may be present atBCI than elsewhere. The site effect was nolonger significant when BCI was omitted from a recoded analysis of deviance model.

\section{Ant species distribution at the seed baits}

We observed 20 ant species belonging to two subfamilies (Myrmicinae and Ponerinae) during the seed removal experiments ran in October-November 2000. The genus with the most species was Pheidole, with four species encountered in the three lowland sites and eight species in the higher-elevation sites. Although half of the ant species were observed at more than one site, no ant species were found in both lowland and higher-elevation sites (Table 5). Most species observed in the lowlands were recorded at more than one site, whereas most species
Table 5. Ant species observed harvesting seeds from the removal experiment in October-November 2000. Abbreviations as for Table 2.

\begin{tabular}{|c|c|c|}
\hline Ant species & Seeds harvested & Site \\
\hline \multicolumn{3}{|l|}{ Myrmicinae } \\
\hline Cyphomyrmex sp. 1 & Luehea, Cecropia & M \\
\hline Cyphomyrmex sp. 2 & Luehea & M \\
\hline Pheidole biconstricta (Mayr) (1)* & Cecropia & $\mathrm{M}, \mathrm{B}, \mathrm{S}$ \\
\hline Pheidole biconstricta (Mayr) (2)* & Trema & $\mathrm{M}, \mathrm{B}, \mathrm{S}$ \\
\hline Pheidole multispina & Miconia, Apeiba & $\mathrm{M}, \mathrm{B}, \mathrm{S}$ \\
\hline Solenopsis (Diplorhoptrum) sp. & Miconia, Apeiba & $\mathrm{M}, \mathrm{B}, \mathrm{S}$ \\
\hline Pheidole sp. 1 & Apeiba & $\mathrm{M}, \mathrm{B}$ \\
\hline Pheidole sp. 2 & Cecropia, Apeiba & $\mathrm{C}$ \\
\hline Pheidole sp. 3 & Cecropia, Apeiba & $\mathrm{C}, \mathrm{F}$ \\
\hline Pheidole sp. 4 & Cecropia, Miconia & $\mathrm{C}, \mathrm{F}$ \\
\hline Pheidole sp. 5 & Cecropia, Trema & $\mathrm{C}$ \\
\hline Pheidole sp. 6 & Cecropia & $\mathrm{C}$ \\
\hline Pheidole sp. 7 & Cecropia, Apeiba, Trema & $\mathrm{F}$ \\
\hline Pheidole sp. 8 & Cecropia, Miconia, Apeiba & $\mathrm{F}$ \\
\hline Pheidole sp. 9 & Cecropia, Apeiba & $\mathrm{F}$ \\
\hline Monomorium sp. & Cecropia & $\mathrm{C}$ \\
\hline Trachymyrmex cornetzi (Wheeler) & Cecropia & $\mathrm{M}, \mathrm{B}$ \\
\hline Sericomyrmex urichi (Mayr) & Cecropia & $\mathrm{M}, \mathrm{B}, \mathrm{S}$ \\
\hline Wasmannia auropunctata (Roger) & Miconia, Apeiba & $\mathrm{M}, \mathrm{B}, \mathrm{S}$ \\
\hline \multicolumn{3}{|l|}{ Ponerinae } \\
\hline Gnamptogenys sp. & Apeiba & $\mathrm{C}$ \\
\hline
\end{tabular}

* Different in some morphological traits perhaps two infra-specific taxa.

from the higher-elevation sites were found either at Cerro Campana or Fortuna.

\section{DISCUSSION}

In this study we examined removal rates of seeds of four animal- and two wind-dispersed pioneer species placed on the soil surface at five sites varying in seasonality and elevation. Seeds were obtained from tree crowns or from freshly fallen intact fruits and were cleaned of fruit pulp and air-dried before initiating the experiment. Although fruit or faecal material may alter the attractiveness of seeds to secondary dispersers (Byrne \& Levey 1993, Kaspari 1993, Loiselle 1990, Pizo \& Oliveira 1999) this initial treatment allowed us to assess the role of seed size and morphology as factors influencing seed 
removal. Despite this pre-treatment, a dramatic difference remained between the fate of animal- and wind-dispersed seeds. Overall, in October-November 2000, between 17 and $96 \%$ of three animal-dispersed seeds were removed from unprotected treatments over $47 \mathrm{~h}$, versus $1-3 \%$ for the two wind-dispersed species.

Differences in removal rates between animal- and winddispersed seeds could have several explanations. Small particles of fruit pulp or other residues present on the seed coat might have acted as a residual attractant to some ant species, particularly in the case of Apeiba seeds, where oily mesocarp tissue remained firmly attached to the seeds. A second possibility is that the large wings on Luehea and Jacaranda seeds may have hindered seed removal. This also seems unlikely as attempts to remove the seeds were not observed in the field, and because removal of the wings of Luehea seeds in May-June 2001 did not substantially increase removal rates relative to other species (Table 3). One final possibility is that invertebrate seed predators may discriminate against wind-dispersed seeds based on their lower seed moisture content (Augspurger 1988).

Most seed removal could be attributed to ants at all sites. Seeds placed on the centre of Petri dishes and surrounded by a barrier of Tanglefoot ${ }^{\circledR}$ to exclude nonvolant invertebrates had very low removal rates (overall $<1 \%$ for all species except Apeiba). Seeds protected from removal from larger vertebrate seed predators by 0.6$\mathrm{mm}$ steel mesh exclosures had similar removal rates as unprotected controls. An exception to this pattern was substantial losses of Apeiba seeds from Tanglefoot (B) exclosures in the two higher-elevation sites, which suggest predation by vertebrates might play a role for the largest seeds used in our experiment.

However, removal rates for Apeiba were not significantly different between caged and un-caged treatments (Table 3; see Results). Instead, Apeiba seed loss at the higher-elevation sites might be accounted for by the activity of large cockroaches (Blattaria), which were occasionally observed removing Apeiba seeds from stations at Fortuna and Cerro Campana but were not observed at the lowland sites. Failure to find evidence for vertebrate seed predation may indicate that the seeds we selected were too small to be attractive to rodents, or alternatively, that the structures used in the experiment may have repelled them.

Patterns of ant abundance and diversity along elevational gradients are as yet poorly defined. In general, insect diversity has been found to peak at mid-elevations (Janzen 1973, Janzen et al. 1976, but see Wolda 1987). Similarly ant diversity and density peak at 400-800 m elevation in the Philippines (Samson et al. 1997), and at $800-1000 \mathrm{~m}$ in Panama, declining to low levels by $1500 \mathrm{~m}$ (Olson 1994). Here, we found no evidence of a significant difference in removal rates of seeds that we could attribute to variation in overall ant activity between the lowland and higher-elevation sites. Seed removal rates were similar among sites with the exception of high rates at BCI (Table 4), and could be attributed to many ant species (Table 5). Clearly litter-ant communities in the lowland and higher elevation sites differed in species composition, but our records of seed removal were not sufficiently detailed to evaluate the specificity of ants to particular species. Nonetheless, the finding that three ant species (Pheidole biconstricta, Trachymyrmex cornetzi and Sericomyrmex urichi) which were common at least in two of the three lowland sites (Table 5), were observed removing seeds of only a single species (Cecropia peltata) is suggestive of some dietary niche partitioning among the litter ants, as has been observed based on seed size (Kaspari 1996).

Overall, our results suggest that seed morphology and dispersal characteristics play a more important role than site characteristics in the post-dispersal seed fate of neotropical pioneers. Further studies need to determine whether the clear differences in removal rates between animal- and wind-dispersed species observed here can be broadly generalized, and should include sites at higher elevations than included here to determine how leaflitter ants influence recruitment patterns of small-seeded species.

\section{ACKNOWLEDGEMENTS}

We thank the Smithsonian Tropical Research Institute (STRI) in Panamá for providing lab, greenhouse and site facilities. The project was partly supported by an outgoing fellowships' programme from Milan University. We further thank Mike Kaspari for helping in ant taxa identification and three anonymous reviewers for interesting and useful comments which improved the manuscript.

\section{LITERATURE CITED}

ALVAREZ-BUYLLA, E. R. \& MARTÍNEZ-RAMOS, M. 1990. Seed bank versus seed rain in the regeneration of tropical pioneer tree. Oecologia 84:314-325.

AUGSPURGER, C. K. 1988. Mass allocation, moisture content and dispersal capacity of wind-dispersed tropical diaspores. New Phytologist 108:357-368.

BYRNE, M. M. \& LEVEY, D. J. 1993. Removal of seeds from frugivore defecations by ants in a Costa Rican rain forest. Vegetatio 107/108:363-374.

CHEKE, A. S., NANAKORN, W.\& YANKOSES, C. 1979. Dormancy and dispersal of seeds of secondary forest species under the canopy of a primary tropical rain forest in northern Thailand. Biotropica 11:8895.

CRAWLEY, M. J. 1993. GLIM for ecologists. Blackwell Scientific Publications, Oxford. 379 pp. 
CROAT, T. B. 1978. Flora of Barro Colorado Island. Stanford University Press, Stanford. 943 pp.

DALLING, J. W. \& HUBBELL, S. P. 2002. Seed size, growth rate and gap microsite conditions as determinants of recruitment success for pioneer species. Journal of Ecology 90:557-568.

DALLING, J.W., SWAINE, M.D.\&GARWOOD, N.C. 1997. Soil seed bank community dynamics in seasonally moist lowland tropical forest, Panama. Journal of Tropical Ecology 13:659-680.

DALLING, J. W., SWAINE, M. D. \& GARWOOD, N. C. 1998. Dispersal patterns and seed bank dynamics of pioneer trees in moist tropical forest. Ecology 79:564-578.

GUEVARA SADA, S. \& GÓMEZ-POMPA, A. 1972. Seeds from surface soils in a tropical region of Veracruz, Mexico. Journal of the Arnold Arboretum 53:312-335.

JANZEN, D. H. 1973. Sweep samples of tropical foliage insects: effects of seasons, vegetation types, elevation, time of day, and insularity. Ecology 54:687-701.

JANZEN, D. H., ATAROFF, M., FARIÑAS, M., REYES, S., RINCON, N., SOLER, A., SORIANO, P. \& VERA, M. 1976. Changes in the arthropod community along an elevational transect in the Venezuelan Andes. Biotropica 8:193-203.

KASPARI, M. 1993. Removal of seeds from Neotropical frugivore droppings. Ant responses to seed number. Oecologia 95:81-88.

KASPARI, M. 1996. Worker size and seed size collection by harvester ants in a Neotropical forest. Oecologia 105:397-404.

KASPARI, M. \& WEISER, M. D. 2000. Ant activity along moisture gradients in a neotropical forest. Biotropica 32:703-711.

LAWTON, R. O. \& PUTZ, F. E. 1988. Natural disturbance and gapphase regeneration in a wind-exposed tropical cloud forest. Ecology 69:764-777.

LEVEY, D. J. \& BYRNE, M. M. 1993. Complex ant-plant interactions: rain forest ants as secondary dispersers and post-dispersal seed predators. Ecology 74:1802-1812.

LEVINGS, S. C. \& WINDSOR, D. M. 1984. Litter moisture content as a determinant of litter arthropod distribution and abundances during the dry season on Barro Colorado Island, Panama. Biotropica 16:125131.

LOISELLE, B. A. 1990. Seeds in droppings of tropical-fruit eating birds: importance of considering seed composition. Oecologia 82:494-500.

McCOY, E. D. 1990. The distribution of insects along elevational gradients. Oikos 58:313-322.

MURRAY, K. G. \& GARCIA, J. M. 2002. Contributions of seed dispersal and demography to recruitment limitation in a Costa Rican cloud forest. Pp.323-338 in Levey, D. J. Silva, W. R. \& Galetti, M. (eds). Seed dispersal and frugivory: ecology, evolution and conservation. CABI International.

O'DOWD, D. J. \& HAY, M. E. 1980. Mutualism between harvester ants and a desert ephemeral: seed escape from rodents. Ecology 61:531540.

OLSON, D. M. 1994. The distribution of leaf litter invertebrates along a Neotropical altitudinal gradient. Journal of Tropical Ecology 10:129150.

PEARSON, T. R. H., BURSLEM, D. F. R. P., MULLINS, C. E. \& DALLING, J.W. 2002. Germination ecology of neotropical pioneers: interacting effects of environmental conditions and seed size. Ecology 83:27982807.

PIZO, M. A. \& OLIVEIRA, P. S. 1999. Removal of seeds from vertebrate faeces by ants: effects of seed species and deposition site. Canadian Journal of Zoology1595-1602.

SAMSON, D. A., RICKART, E. A. \& GONZALES, P. C. 1997. Ant diversity and abundance along an elevational gradient in the Philippines. Biotropica 29:349-363.

SILVERA, K., SKILLMAN, J. B. \& DALLING, J. W. 2002. Seed germination, seedling growth and habitat partitioning in two morphotypes of the tropical pioneer tree Trema micrantha in a seasonal forest in Panama. Journal of Tropical Ecology 19:27-34.

WHITMORE, T. C. 1983. Secondary succession from seed in tropical rain forests. Forestry Abstracts 44:767-779.

WOLDA, H. 1987. Altitude, habitat and tropical insect diversity. Biological Journal of the Linnean Society 30:313-323. 